\title{
Nodular Lymphocyte Predominant Hodgkin Lymphoma
}

National Cancer Institute

\section{Source}

National Cancer Institute. Nodular Lymphocyte Predominant Hodgkin Lymphoma. NCI

Thesaurus. Code C7258.

A monoclonal B-cell neoplasm characterized by a nodular, or a nodular and diffuse proliferation of scattered large neoplastic cells known as popcorn or lymphocyte predominant cells (LP cells)- formerly called L\&H cells for lymphocytic and/or histiocytic Reed-Sternberg cell variants. The LP cells lack CD15 and CD30 in nearly all instances.

Patients are predominantly male, frequently in the 30-50 year age group. Most patients present with limited stage disease (localized peripheral lymphadenopathy, stage I or II). (WHO 2008) 